\title{
PENERAPAN PROSES MENULIS BERBASIS PORTOFOLIO BERBANTUAN MEDIA GAMBAR UNTUK MENINGKATKAN HASIL BELAJAR BAHASA INDONESIA KELAS IV
}

\author{
I Gede Margunayasa ${ }^{1, *}$, I Wayan Widiana ${ }^{2}$, Nyoman Budi Artawan ${ }^{3}$ \\ 1 Jurusan Pendidikan Guru Sekolah Dasar. Universitas Pendidikan Ganesha, Indonesia \\ 2 Jurusan Pendidikan Guru Sekolah Dasar. Universitas Pendidikan Ganesha, Indonesia \\ 3 Jurusan Pendidikan Guru Sekolah Dasar. Universitas Pendidikan Ganesha, Indonesia
}

\begin{abstract}
Abstrak
Penelitian ini bertujuan untuk mengetahui hasil belajar siswa setelah penerapan proses menulis berbasis portofolio berbantuan media gambar untuk meningkatkan hasil belajar bahasa Indonesia kelas IV SD No. 6 panji. PTK ini dilaksanakan dalam dua siklus yang masing-masing siklus dilaksanakan empat kali pertemuan. Subjek penelitian ini adalah siswa kelas IV SD No. 6 Panji yang terdiri dari 19 orang siswa, yaitu 13 orang siswa laki-laki dan 6 orang siswa perempuan. Pengumpulan data dalam penelitian ini menggunakan metode tes. Selanjutnya data yang terkumpul dianalisis dengan teknik deskriptif kuantitatif. Hasil penelitian menunjukkan adanya peningkatan hasil belajar bahasa Indonesia siswa kelas IV SD No. 6 Panji. Persentase hasil belajar siswa mengalami peningkatan, terbukti dari hasil yang diperoleh pada siklus I dengan nilai 77,10 dan pada siklus II menjadi 88,40 yang termasuk ke dalam kategori tinggi, sedangkan siswa yang mencapai ketuntasan dari 17 orang siswa menjadi 18 orang siswa dan ketuntasan klasikal pada siklus I sebesar 77,10\% menjadi $88,40 \%$ pada siklus II. Dengan demikian penerapan penerapan proses menulis berbasis portofolio berbantuan media gambar dapat meningkatkan hasil belajar siswa kelas IV SD No. 6 Panji.
\end{abstract}

\section{Keywords:}

Proses menulis, portofolio, media gambar, hasil belajar

\section{Pendahuluan}

Upaya untuk meningkatkan mutu pendidikan di sekolah adalah dengan cara melalui perbaikan proses belajar. Berbagai konsep dan wawasan baru tentang belajar mengajar di sekolah telah muncul dan berkembang seiring pesatnya perkembangan ilmu pengetahuan dan teknologi. Guru sebagai personel yang menduduki posisi strategis dalam rangka pengembangan sumber daya manusia, dituntut untuk terus mengikuti berkembangnya konsep-konsep baru dalam dunia pendidikan.

Salah satu upaya yang dilakukan pemerintah dengan merubah KBK (kurikulum berbasis kompetensi) menjadi KTSP (kurikulum tingkat satuan pendidikan). Kurikulum ini dimaksudkan untuk mengembangkan kompetensi siswa, yang meliputi pengetahuan, keterampilan, dan sikap serta minat siswa, pada setiap mata pelajaran yang tercantum di dalam kurikulum itu. Oleh karena itu, penilaian pembelajaran atau penilaian hasil belajar dalam pelaksanaan KTSP perlu dilakukan berdasarkan informasi yang selengkap mungkin mengenai siswa yang bersangkutan agar maksud tersebut terlaksana.

KTSP mencakup kegiatan pembelajaran dan merupakan situasi yang memungkinkan terjadinya interaksi antara guru, siswa dan bahan pembelajaran secara teratur. Komponen kegiatan pembelajaran di sekolah terdiri dari siswa, guru, tujuan, isi pelajaran, model, media dan evaluasi. Di antara komponen ini guru memegang peranan yang sangat penting untuk mencapai tujuan pembelajaran, untuk itu seorang guru dituntut untuk mempunyai skill, strategi dan memerlukan kreativitas, aktivitas, maupun pembaharuan-pembaharuan dalam teknis, sarana dan prasarana, metode dan lain-lain.

Pada pembelajaran di kelas, evaluasi hasil pembelajaran lazimnya dilakukan oleh pihak dalam (guru). Akan tetapi, mungkin pula evaluasi dilakukan oleh pihak luar (misalnya pemerintah), Pihak luar

\footnotetext{
* Corresponding author.

E-mail Addresses igede.margunayasa@undiksha.ac.id (I Gede Margunayasa), wayan widiana@yahoo.co.id (I Wayan Widiana),

asihmarta@yahoo.com (Nyoman Budi Artawan)
} 
perlu menilai untuk keperluan penentuan mutu dan untuk kriteria penyaringan. Di samping itu, guru memerlukan dukungan dari pihak luar untuk menentukan ukuran atau standar kompetensi, dalam rangka menyesuaikan pembelajarannya dengan kebutuhan masyarakat luas. Pihak dalam perlu mengadakan penilaian untuk membuat keputusan tentang pembelajaran; misalnya: dalam hal apa pembelajaran perlu diperbaiki, siswa mana yang memerlukan tambahan bantuan, seberapa jauh hasil pembelajaran sesuai dengan tujuan yang telah ditentukan dalam kurikulum, dirumuskan dalam rencana pembelajaran, dan sebagainya. Dengan kata lain, penilaian oleh pihak guru harus menghasilkan tindakan untuk meningkatkan pembelajaran atau hasil belajar.

Adapun permasalahan yang dihadapi dan dirasakan dalam pendidikan sekarang ini adalah mutu dan kualitas pendidikan yang masih kurang. Biasanya orang berbicara masalah pendidikan hanyalah berdasarkan pada out put dan nilai-nilai (nilai tes formatif, nilai tes sumatif ataupun nilai UAN) yang diperoleh siswa secara komulatif dan masih kurang mengkaitkannya dengan proses. Penyempurnaan metode dan strategi pembelajaran maupun model-model yang digunakan dalam pembelajaran dilakukan untuk mendorong minat dan semangat siswa agar lebih kreatif dan inovatif untuk mengetahui dan memahami setiap mata pelajaran.

Dilihat dari kenyataan di lapangan bahwa sebagian besar guru sekolah dasar masih kurang memperhatikan siswa dalam proses menulis dengan menggunakan tulisan tegak bersambung, sehingga tulisan siswa masih kurang rapi serta guru belum mengerti dalam penggunaan penilaian portofolio dalam kegiatan pembelajarannya. Penguasaan mata pelajaran bahasa Indonesia di kelas IV bagi siswa sangatlah penting untuk menunjang keberhasilan pada tingkat pengetahuan dan pemahaman siswa tentang empat aspek pembelajaran bahasa Indonesia seperti: menulis (menggunakan tegak bersambung), membaca (menggunakan laval, intonasi, mimik serta jeda), mendengarkan (mampu menyimak dan memahami tiap materi), berbicara (mampu mengungkapkan materi yang telah dipahaminya baik secara individual maupun kelompok) serta akan menjadi sasaran yang ampuh untuk mempelajari mata pelajaran yang lain baik pada jenjang sekolah dasar maupun ke jenjang pendidikan berikutnya.

Kenyataan menunjukkan bahwa hasil belajar mata pelajaran bahasa Indonesia pada siswa kelas IV semester I di Sekolah Dasar No. 6 Panji Kecamatan Sukasada, Kabupaten Buleleng tahun pelajaran 2010/2011 dalam kategori nilai rata-rata 72 (sumber: daftar nilai kelas IV semester I). Hal ini dikarenakan guru dalam proses pembelajaran masih didominasi dengan menggunakan metode ceramah dan kurangnya penggunaan media pembelajaran. Adapun rincian nilai bahasa Indonesia tersebut dapat diuraikan sebagai berikut: aspek mendengarkan (74), aspek berbicara (71), aspek membaca (72) dan aspek menulis (71). Untuk itu dalam penelitian tindakan kelas ini akan diterapkan proses menulis berbasis portofolio berbantuan media gambar dalam mata pelajaran bahasa Indonesia siswa kelas IV semester II di Sekolah Dasar No. 6 Panji Kecamatan Sukasada, Kabupaten Buleleng tahun pelajaran 2010/2011 yang bertujuan untuk meningkatkan hasil belajarnya.

\section{Metode}

Dalam penelitian ini, jenis penelitian tindakan yang akan digunakan adalah penelitian tindakan model kolaboratif, yaitu kolaborasi atau kerjasama antara guru dan peneliti. Peneliti merancang penelitian yang akan dilaksanakan dan menyiapkan instrumen evaluasi pembelajaran. Guru ikut terlibat dalam pembelajaran dan perencanaan tindakan yang akan dilaksanakan, serta melaksanakan pembelajaran sesuai dengan skenario yang sudah disiapkan bersama. Penelitian ini direncanakan dalam beberapa siklus, tiap siklus terdiri dari empat tahapan yaitu perencanaan, pelaksanaan, observasi, dan refleksi. Jika sudah memenuhi hasil yang diharapkan maka siklus tidak dilanjutkan lagi.

Dalam penelitian ini terdapat dua variabel yang menjadi fokus perhatian yakni proses menulis dan hasil belajar. Keterampilan menulis merupakan suatu proses menghasilkan suatu tulisan yang dimulai dari menuangkan pikirannya kedalam suatu tulisan dan keterampilan tersebut memberikan kesempatan kepada siswa untuk berkomunikasi secara tertulis baik formal maupun informal.

Penilaian portofolio merupakan suatu pembelajaran yang dilakukan untuk mengumpulkan hasil karya siswa yang dapat memberikan informasi bagi suatu penilaian, dimana kumpulan hasil kerja siswa tersebut berisi pekerjaan siswa selama waktu tertentu yang dapat memberi informasi bagi suatu penilaian yang objektif, yang menunjukkan apa yang dapat dilakukan siswa dalam lingkungan dan suasana belajar yang alami.

Media visual (gambar) adalah media yang hanya mengandalkan indera penglihatan. Media gambar tanda baca sangat mendukung pembelajaran karena dapat menarik perhatian siswa dalam mengikuti pelajaran dan nantinya diharapkan akan menambah tingkat pemahaman siswa serta meningkatkan hasil belajar siswa dalam mata pelajaran bahasa Indonesia. 
Hasil belajar bahasa Indonesia adalah suatu hasil belajar yang diperoleh siswa berdasarkan usaha sebagai akibat dari proses pengalaman dalam kurun waktu tertentu, dalam proses belajar bahasa Indonesia hasil belajar yang dicapai siswa mencakup tiga ranah yaitu ranah kognitif, afektif dan psikomotor. Hasil belajar bahasa Indonesia diukur dengan metode tes yang berupa tes uraian. Dengan cara demikian, maka data tentang hasil belajar bahasa Indonesia yang diperoleh bersifat interval/skor.

Penelitian ini direncanakan akan dilaksanakan melalui dua siklus masing-masing siklus terdiri dari empat tahap yaitu (a) perencanaan tindakan, (b) pelaksanaan tindakan, (c) pemantauan/observasi dan evaluasi, (d) refleksi.

Dalam penelitian ini teknik pengumpulan data yang digunakan adalah tes. Instrumen pengumpulan data yang digunakan adalah seperangkat tes. Selanjutnya penelitian tindakan kelas ini menggunakan dua teknik analisis data yaitu, teknik analisis statistik deskriptif, dan teknik deskriptif kuantitatif. Agung (2010) menjelaskan bahwa teknik analisis statistik deskriptif adalah cara pengolahan data yang dilakukan dengan jalan menerapkan rumus-rumus statistik deskriptif seperti distribusi frekuensi, grafik, angka rata-rata (Mean), median (Me), dan modus (Mo) untuk menggambarkan keadaan suatu objek tertentu sehingga diperoleh kesimpulan umum. Teknik analisis kuantitatif adalah "suatu cara pengelolaan data yang dilakukan dalam bentuk angka-angka dan persentase mengenai obyek yang diteliti sehingga diperoleh kesimpulan umum" (Agung, 2010). Agung memaparkan bahwa teknik analisis kuantitatif adalah penarikan kesimpulan umum berdasarkan pengelolaan data dalam bentuk angka-angka dan persentase.

Teknik analisis deskriptif kuantitatif ini digunakan untuk menentukan tingkatan tinggi rendahnya hasil belajar bahasa Indonesia siswa yang dikonversikan ke dalam Penilaian Acuan Patokan (PAP) skala lima.

\section{Hasil Dan Pembahasan}

Penelitian tindakan kelas ini dilaksanakan di kelas IV SD No. 6 Panji dengan jumlah siswa sebanyak 19 orang. Penelitian tindakan kelas pada mata pelajaran bahasa Indonesia ini dilaksanakan dalam dua siklus pembelajaran, siklus pertama dibagi menjadi empat kali pertemuan dan siklus kedua dibagi menjadi empat kali pertemuan, yaitu tiga kali pertemuan untuk penyampaian materi dan hasil kerja siswa dengan menggunakan model proses menulis berbantuan media gambar tanda baca kemudian diakhiri dengan satu kali pertemuan untuk tes akhir siklus.

Pada tahap refleksi awal, peneliti mencari skor terakhir hasil belajar siswa kelas IV SD No. 6 Panji berdasarkan skor awal tes kompetensi dasar yang diperoleh siswa pada mata pelajaran bahasa Indonesia di kelas IV. Pencarian skor ini dimaksudkan untuk mengetahui hasil belajar bahasa Indonesia siswa sebelum dilaksanakan tindakan. Data ini digunakan untuk lebih menguatkan hasil observasi dan wawancara yang telah dilakukan, bahwa di kelas tersebut hasil belajar bahasa Indonesia siswa masih rendah. Data skor tes hasil belajar siswa pada refleksi awal juga digunakan untuk mengetahui skor kemajuan individu. Secara terperinci data skor awal hasil belajar bahasa Indonesia siswa pada refleksi awal disajikan dalam tabel 1.

Gambar 1 Skor Awal Tes Siswa Kelas IV SD No. 6 Panji

\begin{tabular}{|llllllllll|}
\hline 70 & 65 & 40 & 70 & 60 & 60 & 65 & 80 & 50 & 70 \\
& 70 & 80 & 45 & 55 & 70 & 75 & 70 & 50 & 55 \\
\hline
\end{tabular}

Selanjutnya pada siklus I, data hasil belajar mata pelajaran bahasa Indonesia yang diperoleh oleh siswa disajikan dalam bentuk tabel distribusi frekuensi, menghitung mean (M), median (Me), Modus (Mo), grafik polygon dan membandingkan rata-rata atau mean dengan model PAP skala lima sehingga memperoleh kesimpulan sangat tinggi, tinggi, sedang, rendah, sangat rendah.

Gambar 2. Data Tes Hasil Belajar Siklus I Siswa Kelas IV SD No. 6 Panji

\begin{tabular}{|llllllllll|}
\hline 45 & 60 & 45 & 95 & 65 & 90 & 90 & 70 & 90 & 75 \\
& 95 & 70 & 65 & 75 & 95 & 90 & 75 & 75 & 90 \\
& & & & & & & & & \\
\hline
\end{tabular}


Selanjutnya dari data yang terkumpul tersebut dapat disajikan ke dalam tabel distribusi frekuensi seperti tabel 1

Tabel 1. Distribusi Frekuensi Data Tes Hasil Belajar Siklus Siswa Kelas IV SD No. 6 Panji

\begin{tabular}{ccccc}
\hline Kelas Interval & Titik Tengah & $\mathrm{F}$ & $\mathrm{fk}$ & $\mathrm{fX}$ \\
\hline $45-51$ & 48 & 2 & 2 & 96 \\
$52-58$ & 55 & 0 & 2 & 0 \\
$59-65$ & 62 & 3 & 5 & 186 \\
$66-72$ & 69 & 2 & 7 & 138 \\
$73-79$ & 76 & 4 & 11 & 304 \\
$80-86$ & 83 & 0 & 11 & 0 \\
$87-93$ & 90 & 5 & 16 & 450 \\
$94-100$ & 97 & 3 & 19 & 291 \\
\hline & & $\mathrm{N}=19$ & & $\sum \mathrm{fX}=1465$ \\
\hline
\end{tabular}

Berdasarkan data tersebut, maka dapat diperoleh rata-rata hasil belajar siswa siklus I sebesar 77,10 dengan presentase 77,10\% yang berada pada kategori sedang.

Selanjutnya, rata-rata tersebut dibandingkan dengan kriteria PAP skala lima. Persentase rata-rata tersebut berada pada kategori 65\%-79\%. Hal ini menunjukan bahwa hasil belajar bahasa Indonesia siklus I berada pada kriteria sedang. Berdasarkan hasil belajar bahasa Indonesia pada siklus I, maka dilanjutkan ke siklus II dengan berpedoman pada hasil refleksi siklus I.

Berdasarkan observasi ditemukan beberapa kekurangan dalam pelaksanaan siklus I. Di antaranya (1) siswa kurang fokus saat mengikuti proses pembelajaran, hal ini dapat dilihat dari perilaku siswa yang masih pasif dalam mengikuti pembelajaran. (2) siswa kurang percaya diri atas jawabannya sendiri sehingga belum berani mengkomunikasikan jawabannya secara individual. (3) pemahaman mengenai penggunaan tanda baca masih kurang. (4) partisipasi siswa dalam memprediksi dan menyimpulkan materi masih kurang.

Berdasarkan refleksi yang telah dilakukan bersama guru, kemudian dilakukan perubahan terhadap tindakan yang dilakukan pada siklus II. Adapun beberapa tindakan yang akan dilakukan antara lain (1) untuk membuat siswa lebih fokus dalam mengikuti pembelajaran, peneliti lebih banyak memberikan tugas yang diselesaikan secara individu sehingga masing-masing siswa memiliki tanggung jawab untuk menyelesaikannya. (2) untuk menumbuhkan rasa percaya diri siswa dalam mengkomukasikan jawabannya, peneliti menawarkan penghargaan berupa kado dan pin yang dapat menambah semangat siswa dalam menjawab tugas dan pertanyaan yang diberikan guru. (3) guru mengkemas media pembelajaran dengan lebih menarik sehingga siswa menjadi tertarik untuk memahaminya. (4) untuk menumbuhkan partisipasi siswa dalam memprediksi dan menyimpulkan materi, peneliti meminta setiap siswa mengeluarkan pendapatnya masing-masing.

Berdasarkan refleksi tersebut, peneliti bersama guru mata pelajaran bahasa Indonesia kembali menyusun rencana pelaksanaan pembelajaran (RPP) yang akan digunakan pada pelaksanaan siklus II. Data hasil belajar mata pelajaran bahasa Indonesia pada siklus II yang diperoleh oleh siswa disajikan dalam bentuk tabel distribusi frekuensi, menghitung mean (M), median (Me), Modus (Mo), grafik polygon dan membandingkan rata-rata atau mean dengan model PAP skala lima sehingga memperoleh kesimpulan sangat tinggi, tinggi, sedang, rendah, sangat rendah.

Gambar 3 Data Hasil Belajar Mata Pelajaran Bahasa Indonesia Siklus II Pada 19 Orang Siswa Kelas IV SD No. 6 Panji

\begin{tabular}{|llllllllll|}
\hline 80 & 95 & 90 & 100 & 85 & 85 & 55 & 90 & 95 & 95 \\
& 100 & 85 & 85 & 95 & 90 & 95 & 80 & 85 & 65 \\
& & & & & & & & & \\
\hline
\end{tabular}

Selanjutnya dari data yang terkumpul tersebut dapat disajikan ke dalam tabel distribusi frekuensi seperti tabel 2. 
Tabel 2 Distribusi Frekuensi Data Tes Hasil Belajar Siklus II Siswa Kelas IV SD No. 6 Panji

\begin{tabular}{cccc}
\hline Kelas Interval & Titik Tengah & F & fX \\
\hline $55-62$ & 58,5 & 1 & 58,5 \\
$63-70$ & 66,5 & 1 & 66,5 \\
$71-78$ & 74,5 & 0 & 0 \\
$79-86$ & 82,5 & 6 & 495 \\
$87-94$ & 90,5 & 31 & 271,5 \\
$95-102$ & 98,5 & 89 & 788 \\
\hline
\end{tabular}

Berdasarkan data tersebut, maka dapat disimpulkan rata-rata hasil belajar siswa siklus II sebesar 88,40 dengan presentase $88,40 \%$ yang berada pada kategori tinggi karena terletak pada tingkat penguasan materi secara klasikal diantara $80 \%$ - 89\%.

Pada siklus II sudah tampak adanya peningkatan pada hasil belajar bahasa Indonesia sebesar $88,40 \%$. Hal ini dapat dilihat dari hasil tes seluruh siswa pada siklus II. Hal-hal yang telah mempengaruhi terjadinya peningkatan hasil belajar bahasa Indonesia pada siklus II ini adalah sebagai berikut. 1) Penggunaan proses menulis berbasis portofolio yang dapat mengajak siswa untuk dapat menyalurkan kemampuannya dalam menulis. 2) Pemberian kado dan pin kepada siswa yang aktif menumbuhkan keberanian siswa dalam menuliskan idenya. 3) Pemberian tugas secara individu yang lebih banyak dapat meningkatkan partisipasi siswa dalam menulis dan menyimpulkan materi. 4) Pemberian pujian yang lebih banyak untuk menumbuhkan rasa percaya diri siswa dalam menjawab pertanyaan dan menuliskan idenya. Berdasarkan refleksi hasil siklus II, dapat disimpulkan bahwa penerapan proses menulis berbasis portofolio berbantuan media gambar tanda baca dalam pembelajaran bahasa Indonesia dapat meningkatkan hasil belajar siswa kelas IV semester II di SD No. 6 Panji, Kecamatan Sukasada, Kabupaten Buleleng

Pembahasan hasil penelitian ini difokuskan pada temuan penting yang dapat meningkatkan hasil belajar siswa dalam penerapan proses menulis dalam pembelajaran bahasa Indonesia. Yaitu (1) penerapan proses menulis dapat meningkatkan kemampuan siswa dalam menulis karangan, (2) rasa percaya diri siswa dapat meningkatkan keaktifan siswa dalam menjawab pertanyaan dan menuliskan idenya, (3) penerapan proses menulis dapat memberikan pemahaman siswa untuk menemukan kebenaran dari tahapan-tahapan penulisan sebuah pengumuman ataupun karangan, (4) pengalaman mengenai kegiatan proses menulis dapat meningkatkan pemahaman siswa terhadap suatu konsep menulis pengumuman ataupun karangan.

Teori-teori yang dikemukakan oleh Dixon dan Nessel maupun Tompkins yang menyatakan metode proses menulis sangat efektif digunakan dalam pembelajaran menulis pengumuman dan karangan ternyata memang sangat bermanfaat untuk meningkatkan hasil belajar siswa.

Penerapan proses menulis dalam proses pembelajaran dapat memberikan peluang kepada siswa untuk mencurahkan segala ide-ide yang dapat digunakan dalam menulis sebuah karangan sehingga aktivitas dan situasi proses pembelajaran menjadi sangat menyenangkan. Dengan terciptanya pembelajaran yang menyenangkan berarti hasil belajar yang diharapkan akan mudah tercapai secara optimal.

Keberhasilan dalam pembelajaran bahasa Indonesia, tidak terlepas dari setiap tahapan atau proses yang dilalui dalam pembelajaran bahasa Indonesia ini. Dengan tumbuhnya rasa percaya diri siswa sangat mendorong siswa dalam meningkatkan kemampuannya dalam menulis sesuai dengan tahapantahapan proses menulis tersebut.

Penerapan proses menulis dapat memberikan pengalaman baru kepada siswa. Dengan memperoleh pengalaman tersebut siswa akan dapat menerapkan konsep-konsep tersebut dalam pembuatan pengumuman ataupun karangan pada mata pelajaran bahasa Indonesia. Langkah-lanngkah yang dilakukan pada saat menulis tersebut dapat menarik perhatian siswa untuk berani mencoba menuangkan ide/pikirannya dalam menulis sebuah pengumuman ataupun karangan. Dalam kegiatan proses menulis ini peneliti dapat mengetahui tingkah laku yang yang dimiliki setiap siswa. Pengalaman 
siswa dalam proses menulis dapat meningkatkan keantusiasan siswa untuk mengikuti proses pembelajaran selanjutnya.

Untuk mencapai hasil yang optimal, selain proses pembelajaran peneliti juga harus mampu merancang rencana pembelajaran yang berpusat pada kegiatan siswa, sehingga dapat meningkatkan hasil belajar siswa. Dalam penelitian ini, setelah penulis menganalisis telah tampak kesesuaian hasil belajar yang diperoleh setiap siswa sehingga tidak terjadi kejanggalan atau ketidaksesuaian dalam penentuan prestasi siswa

Jadi, penerapan proses menulis berbasis portofolio berbantuan media gambar dalam pembelajaran bahasa Indonesia dapat meningkatkan hasil belajar siswa. Hal ini terlihat dari hasil belajar siswa diperoleh persentase sebelum tindakan sebesar $71 \%$ setelah diberikan tindakan pada siklus I sebesar 77,10\% dan siklus II sebesar 88,40\%. Jadi mengalami peningkatan dari siklus I ke siklus II sebesar $11,30 \%$

\section{Simpulan Dan Saran}

Berdasakan rumusan masalah dan hasil penelitian, dapat ditarik simpulan sebagai berikut. Penerapan proses menulis berbasis portofolio berbantuan media gambar dalam pembelajaran bahasa Indonesia dapat meningkatkan hasil belajar pada siswa kelas IV SD No. 6 Panji, Kecamatan Sukasada. Hal ini dapat dilihat dari adanya peningkatan skor hasil belajar siswa pada siklus I diperoleh skor 77,10 atau sekitar $77,10 \%$ dan pada kriteria PAP skala 5 ternyata berada pada kategori sedang, sedangkan pada siklus II diperoleh skor sebesar 88,40 atau sekitar 88,40\% dan pada kriteria PAP skala 5 ternyata berada pada kategori tinggi. Jadi hasil belajar siswa mengalami peningkatan dari siklus I ke siklus II sebesar $11,30 \%$.

Berdasarkan temuan-temuan dalam penelitian ini, dapat disampaikan saran-saran sebagai berikut. 1) Pihak sekolah hendaknya mampu mensosialisasikan dan mengembangkan wawasan mengenai penerapan proses menulis berbasis portofolio dalam pembelajaran agar dapat terjadi peningkatan hasil pembelajaran. 2) Guru mata pelajaran bahasa Indonesia hendaknya meningkatkan pemahaman terhadap pembelajarannya dengan menerapkan proses menulis berbasis portofolio sehingga dapat meningkatkan hasil belajar siswa. 3) Siswa hendaknya lebih memahami mata pelajaran bahasa Indonesia, sebab tanpa pemahaman siswa tidak akan dapat menuliskan apa yang seharusnya dituliskan pada pembelajaran di kelas.

\section{Daftar Pustaka}

Abimanyu, Soli, dkk. 2008. Strategi Pembelajaran. Ditjen pendidikan Tinggi.

Agung, A.A. Gede. 2010. Penelitian Tindakan Kelas (Teori dan Analisis Data dalam PTK). Makalah disajikan pada Workshop Jurusan Pendidikan Guru Sekolah Dasar FIP Undiksha. Singaraja 27 September 2010.

------. 2005. Metodologi Penelitian Pendidikan. Singaraja: Fakultas Ilmu Pendidikan IKIP Negeri Singaraja.

Arikunto, Suharsimi, Suhardjono, Supardi. Penelitian Tindakan Kelas. Jakarta: PT Bumi Aksara.

Depdiknas. 2004. Pedoman Pengembangan portofolio untuk penilaian. Jakarta: Departemen Pendidikan Nasional, Direktorat Jenderal Pendidikan Dasar dan Menengah, Direktorat Pendidikan Menengah Umum.

Dibia, Ketut, dkk. 2007. Pendidikan Bahasa Indonesia 2. Singaraja : Undiksha.

Djauhar, Siddiq, dkk. 2008. Pengembangan Bahan Pembelajaran SD. Jakarta: Direktorat Jenderal Pendidikan Tinggi Departemen Pendidikan Nasional.

Fajar, Arnie. 2002. Portofolio dalam pembelajaran IPS. Bandung: PT Remaja Rosdakarya.

Hakim. 2010. Model Pembelajaran Kooperatif. Tersedia pada http://blog.unm.ac.id/hakim/2010/02/16/model-pembelajarankooperatif/ (diakses tanggal 10 April 2010).

Kunandar. 2007. Guru Profesional Implementasi Kurikulum Tingkat Satuan Pendidikan (KTSP) dan Persiapan Menghadapi Setifikasi Guru. Jakarta: PT Raja Grafindo Persada.

Mikarsa, Prianto, dkk. 2007. Pendidikan Anak di SD. Jakarta: Universitas Terbuka. 
Rakhmat, Cece dan Suherdi. 1998/1999. Evaluasi Pengajaran. Jakarta: Departemen Pendidikan dan Kebudayaan Direktorat Jenderal Pendidikan Tinggi Proyek Pendidikan Guru Sekolah Dasar.

Santosa, Sutejo, dkk. 2008. Materi dan Pembelajaran Bahasa Indonesia SD. Jakarta: Universitas Terbuka.

Sudrajat,Akhmad. 2008. Tersedia pada http://www.psbpsma.org/content/blog/pengertian-pendekatanstrategi-metode-teknik-taktik-dan-model-pembelajaran (diakses tanggal, 17 Oktober 2010).

Suderajat dan Sumarna. 2009. Tersedia pada http://tsauri28.myhaley.com/blog/penilaian-portofolioonline/ (diakses tanggal, 17 Oktober 2010).

Sumantri dan Permana. 1998/1999. Strategi Belajar Mengajar. Jakarta: Departemen Pendidikan dan Kebudayaan Direktorat Jenderal Pendidikan Tinggi Proyek Pendidikan Guru Sekolah Dasar.

Suprayeki, Dicky, dkk. 2008. Pembaharuan Pembelajaran di SD. Jakarta: Universitas Terbuka.

Suranata, Kadek. 2009. Pedoman Pengembangan Penilaian Portofolio. Singaraja: Fakultas Ilmu Pendidikan UNDIKSHA Singaraja.

Tegeh, I Made. 2008. Media Pembelajaran. Malang: Penelitian Disertasi Program Doktor Teknologi Pembelajaran dan Program Pascasarjana Universitas Negeri Malang.

Undiksha. 2009. Pedoman Penulisan Sekripsi dan Tugas Akhir. Singaraja: Undiksha Singaraja.

Wiranataputra, Udin S, dkk. 2007. Teori Belajar dan Pembelajaran. Jakarta: Universitas Terbuka.. 